Article

\title{
Gelation Behavior of 5-Chloro-8-hydroxyquinoline, an Antituberculosis Agent in Aqueous Alcohol Solutions
}

\author{
Erkki Kolehmainen *, Hannu Salo and Jukka Korpela \\ Department of Chemistry, University of Jyväskylä, P.O. Box 35, FIN-40014 Jyväskylä, Finland; \\ E-Mails: hannu.t.salo@jyu.fi (H.S.); jukka.p.korpela@jyu.fi (J.K.) \\ * Author to whom correspondence should be addressed; E-Mail: erkki.t.kolehmainen@jyu.fi; \\ Tel.: +358-40-805-3695; Fax: +358-14-260-2501.
}

Received: 30 July 2012; in revised form: 23 August 2012 / Accepted: 10 September 2012 /

Published: 19 September 2012

\begin{abstract}
It was shown that 5-chloro-8-hydroxyquinoline, an antituberculosis agent, gels aqueous alcohol solutions efficiently. Thermal stability and gel-to-sol transition temperature of $1 \%$ gel in $\mathrm{CD}_{3} \mathrm{OD} / \mathrm{D}_{2} \mathrm{O}(2: 1)$ was studied by ${ }^{1} \mathrm{H}-\mathrm{NMR}$. Fibrous structures of four xerogels have been characterized by scanning electron microscope.
\end{abstract}

Keywords: gel; 5-chloro-8-hydroxyquinoline; Mycobacterium tuberculosis

\section{Introduction}

Tuberculosis (TB) is one of the most serious infectious diseases caused by a single pathogen. One-third of the human population is reported to be latently infected with Mycobacterium tuberculosis, and millions of lives are lost every year [1].

In addition to many known antituberculosis drugs in use [2], 5-chloro-8-hydroxyquinoline or 5-chloroquinol-8-ol (Cloxyquine) has shown to incur in vitro activities against Mycobacterium tuberculosis [3]. Also, 8-hydroxyquinoline itself is effective against Mycobacterium tuberculosis [4] and some derivatives are shown to act as antibacterial agents that target intra- and extracellular Gram-negative pathogens [5]. Further, a novel polymorph of 5-chloro-8-hydroxyquinoline with improved water solubility and faster dissolution rate has been reported which can improve the bioavailability of the drug [6]. In addition, tacrine-8-hydroxyquinoline hybrids have been shown to have potential as multifunctional agents for the treatment of Alzheimer's disease and have copper(II) complexing properties [7]. It has also been recently shown that some related mixed ligand transition 
metal complexes have antituberculosis activity [8]. The importance of mixed ligand transition metal complexes in drug development is further, more generally, described $[9,10]$

Drug resistance in Mycobacterium tuberculosis was shown to be related to pharmacokinetic/ pharmacodynamic (PK/PD) factors [11]. Therefore the gelation ability of this potential drug in aqueous solution can be of extreme importance owing to its usability in controlled release applications [12].

In conjunction with our interest in low molecular weight supramolecular (self assembling) gelators [13] we are now reporting our study on the gelation behavior of 5-chloro-8-hydroxyquinoline in aqueous alcohol solutions. These gelation properties can probably be related also with the supramolecular synthon pattern in solid cloxiquine, reported recently [14]. We consider that these results can help in tailoring better drug delivery and pharmaceutical formulation combating tuberculosis.

\section{Results and Discussion}

Figure 1 shows the structure and numbering of 5-chloro-8-hydroxyquinoline.

Figure 1. The structure and numbering of 5-chloro-8-hydroxyquinoline.

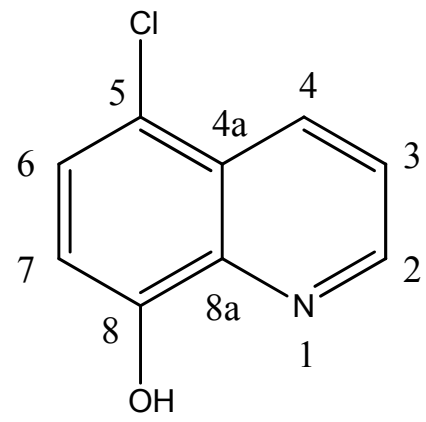

Table 1 lists the gelation data in various aqueous alcohol solutions at $295 \mathrm{~K}$. The gel formation was observed by the test tube inversion method. Systematic temperature studies of all gels were not performed. However, for $1 \%$ 5-chloro-8-hydroxyquinoline gel in $\mathrm{CD}_{3} \mathrm{OD} / \mathrm{D}_{2} \mathrm{O}$ (2:1) the gel-to-sol temperature was between $+28{ }^{\circ} \mathrm{C}$ and $+30{ }^{\circ} \mathrm{C}$ observed by ${ }^{1} \mathrm{H}-\mathrm{NMR}$.

Table 1. Gelation data of 5-chloro-8-hydroxyquinoline (cloxiquine).

\begin{tabular}{ccc}
\hline Entry & Solvent system & [cloxiquine] gel stability \\
\hline 1 & $1: 1 \mathrm{EtOH} / \mathrm{H}_{2} \mathrm{O}$ & $1.0 \%$ very stable \\
2 & $1: 1 \mathrm{EtOH} / \mathrm{H}_{2} \mathrm{O}$ & $0.75 \%$ stable \\
3 & $1: 1 \mathrm{EtOH} / \mathrm{H}_{2} \mathrm{O}$ & $0.5 \%$ stable \\
4 & $1: 2 \mathrm{EtOH} / \mathrm{H}_{2} \mathrm{O}$ & $1.0 \%$ stable \\
5 & $1: 2 \mathrm{EtOH} / \mathrm{H}_{2} \mathrm{O}$ & $0.5 \%$ stable \\
6 & $1: 2 \mathrm{EtOH} / \mathrm{H}_{2} \mathrm{O}$ & $0.2 \%$ poor \\
7 & $1: 4 \mathrm{EtOH} / \mathrm{H}_{2} \mathrm{O}$ & $1.0 \%$ stable \\
8 & $2: 1 \mathrm{MeOH} / \mathrm{H}_{2} \mathrm{O}$ & $1.0 \%$ very stable \\
9 & $2: 1 \mathrm{MeOH} / \mathrm{H}_{2} \mathrm{O}$ & $0.75 \%$ stable \\
10 & $2: 1 \mathrm{MeOH} / \mathrm{H}_{2} \mathrm{O}$ & $0.5 \%$ precipitate \\
11 & $1: 2 \mathrm{MeOH} / \mathrm{H}_{2} \mathrm{O}$ & $1.0 \%$ precipitate \\
12 & $1: 4 \mathrm{MeOH} / \mathrm{H}_{2} \mathrm{O}$ & $1.0 \%$ precipitate \\
\hline
\end{tabular}


Table 1. Cont.

\begin{tabular}{ccc}
\hline Entry & Solvent system & [cloxiquine] gel stability \\
\hline 13 & $2: 11-\mathrm{PrOH} / \mathrm{H}_{2} \mathrm{O}$ & $1.0 \%$ precipitate \\
14 & $1: 11-\mathrm{PrOH} / \mathrm{H}_{2} \mathrm{O}$ & $2.0 \%$ very stable \\
15 & $1: 11-\mathrm{PrOH} / \mathrm{H}_{2} \mathrm{O}$ & $1.0 \%$ stable \\
16 & $1: 11-\mathrm{PrOH} / \mathrm{H}_{2} \mathrm{O}$ & $0.75 \%$ poor \\
17 & $1: 11-\mathrm{PrOH} / \mathrm{H}_{2} \mathrm{O}$ & $0.5 \%$ precipitate \\
18 & $1: 21-\mathrm{PrOH} / \mathrm{H}_{2} \mathrm{O}$ & $1.0 \%$ stable \\
19 & $1: 41-\mathrm{PrOH} / \mathrm{H}_{2} \mathrm{O}$ & $1.0 \%$ stable \\
20 & $1: 41-\mathrm{PrOH} / \mathrm{H}_{2} \mathrm{O}$ & $0,5 \%$ stable \\
21 & $1: 41-\mathrm{PrOH} / \mathrm{H}_{2} \mathrm{O}$ & $0.2 \%$ stable \\
22 & $1: 41-\mathrm{PrOH} / \mathrm{H}_{2} \mathrm{O}$ & $0.1 \%$ stable \\
23 & $1: 81-\mathrm{PrOH} / \mathrm{H}_{2} \mathrm{O}$ & $1.0 \%$ precipitate \\
24 & $1: 101-\mathrm{PrOH} / \mathrm{H}_{2} \mathrm{O}$ & $1.0 \%$ precipitate \\
25 & $1: 12-\mathrm{PrOH} / \mathrm{H}_{2} \mathrm{O}$ & $2.0 \%$ stable \\
26 & $1: 12-\mathrm{PrOH} / \mathrm{H}_{2} \mathrm{O}$ & $1.0 \%$ stable \\
27 & $1: 12-\mathrm{PrOH} / \mathrm{H}_{2} \mathrm{O}$ & $0.5 \%$ stable \\
28 & $1: 12-\mathrm{PrOH} / \mathrm{H}_{2} \mathrm{O}$ & $0.2 \%$ poor \\
29 & $1: 22-\mathrm{PrOH} / \mathrm{H}_{2} \mathrm{O}$ & $1 \%$ (g) stable \\
30 & $1: 42-\mathrm{PrOH} / \mathrm{H}_{2} \mathrm{O}$ & $1 \%$ precipitate \\
\hline
\end{tabular}

As can be seen, increasing the concentration of 5-chloro-8-hydroxyquinoline results in a better stability of the formed gels. However, 5-chloro-8-hydroxyquinoline is not a real hydrogelator because increasing the water molar ratio generally results in a precipitate formation.

In addition, the topography of the gels was characterized by the electron microscopy. Four xerogels have been characterized by scanning electron microscopy (SEM), as described in Figures 2-5.

Figure 2. SEM image of xerogel from 1:1 EtOH/water 1\% gel.

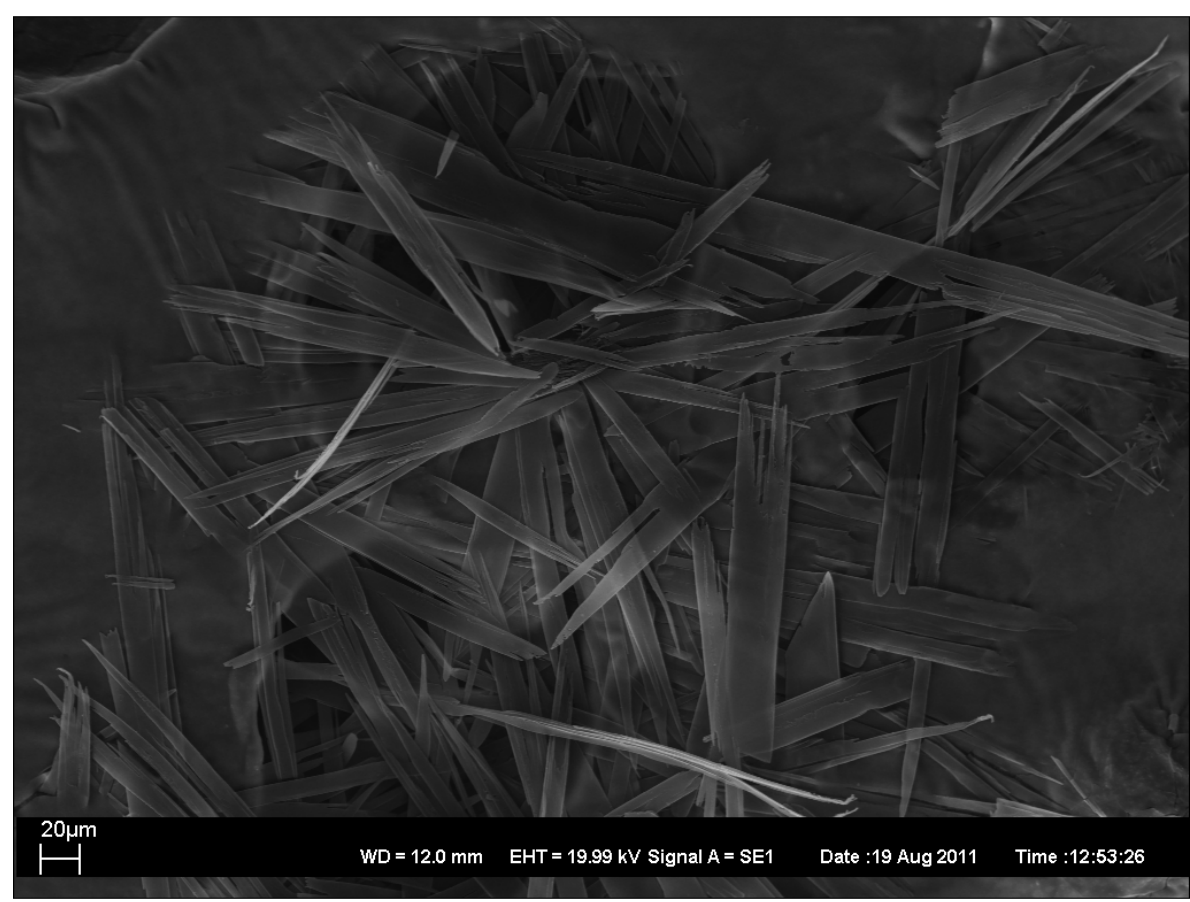


Figure 3. SEM image of xerogel from 2:1 MeOH/water 1\% gel.

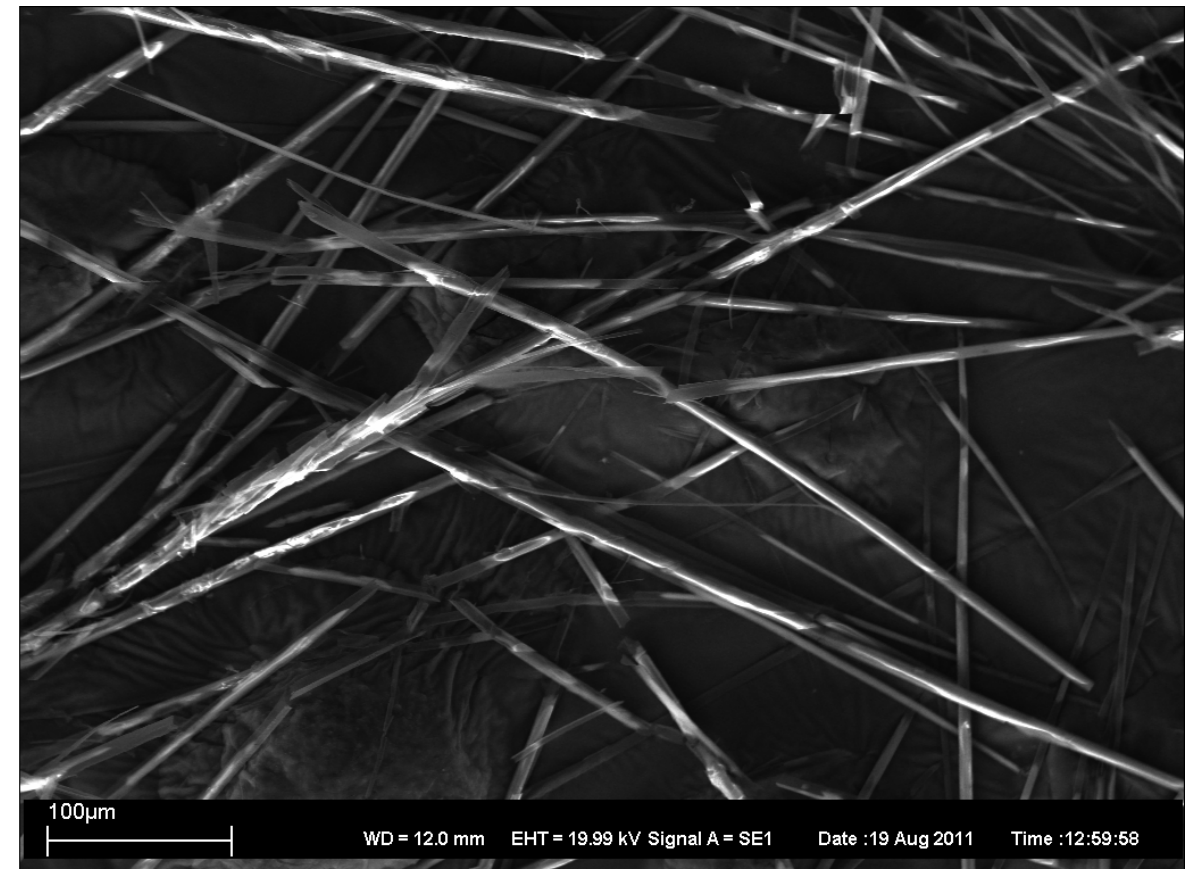

Figure 4. SEM image of xerogel from 1:1 1-PrOH/water 2\% gel.

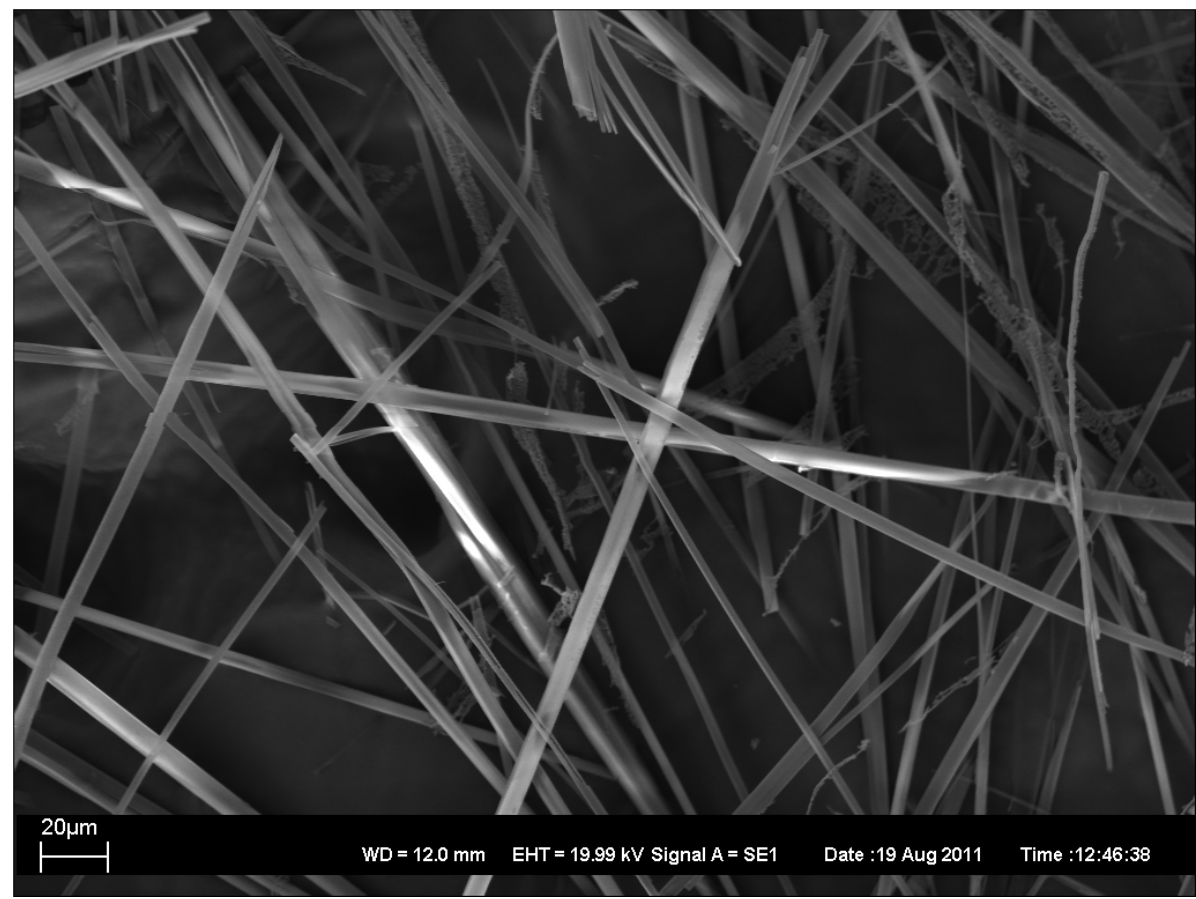


Figure 5. SEM image of xerogel from 1:1 1-PrOH/water 1\% gel.

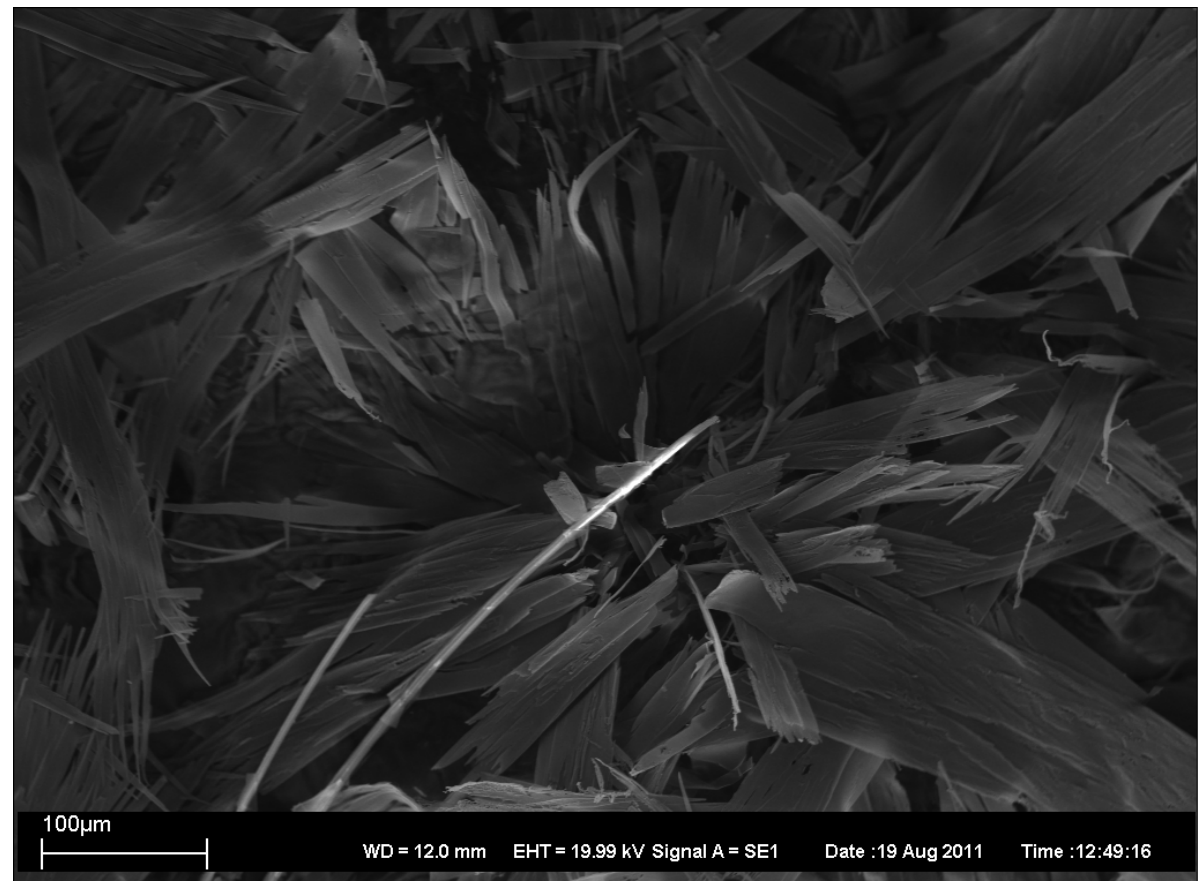

As can be seen, SEM images 2-5 revealed the presence of long rod-like structures with variable rod diameters. However, there exists some variation in the width and the length of the rods. In xerogels from 1:1 EtOH/water 1\% gel (Figure 2) and from 1:1 1-PrOH/water 1\% gel (Figure 5) the width variation is clearly larger and the average widths is greater than in the others (Figures 3 and 4) which also show less bundled structures. In all xerogels, rods reveal no or very weak branching and the overall structure can thus be considered as an open-type network. The fractures of the network seen in Figure 5 are probably due to the faster evaporation of the solvent.

The gel-to-sol transformation was studied by variable temperature NMR. This technique was successfully used recently in gel-to-sol transformation studies [15]. Figure 6 describes $500 \mathrm{MHz}$ ${ }^{1} \mathrm{H}$-NMR spectra of $1.0 \%$ 5-chloro-8-hydroxyquinoline in $\mathrm{CD}_{3} \mathrm{OD} / \mathrm{D}_{2} \mathrm{O}(2: 1)$ from $+18{ }^{\circ} \mathrm{C}$ (bottom) to $+30{ }^{\circ} \mathrm{C}$ (top) in $2{ }^{\circ} \mathrm{C}$ steps. As can be seen, a clear increase in the signal intensity happens between $+28{ }^{\circ} \mathrm{C}$ and $+30{ }^{\circ} \mathrm{C}$. This means that the number of motionally limited or NMR "silent" molecules of the gel [16] decreases significantly between these two temperatures owing to the gel-to-sol transformation where the molecular motion of 5-chloro-8-hydroxyquinoline is no longer restricted. Although this gel-to-sol change happens below the physiological conditions this finding suggests that the gel stability could be improved by other modifications of solvent systems.

\section{Experimental}

5-Chloro-8-hydroxyquinoline (95\%) was purchased from Sigma-Aldrich and used without purification because its ${ }^{1} \mathrm{H}-\mathrm{NMR}$ spectrum did not reveal any impurity signals [17]. All solvents were also from commercial sources and used as obtained. Deionized water was from our own laboratory. The samples were prepared by weighing an accurate amount of 5-chloro-8-hydroxyquinoline in a known volume of the solvent system in a test tube. After that the mixture was heated in a water bath until the solute dissolves. Then the test tube was closed and allowed to cool to room temperature. The 
gel formation was detected by the tube inversion technique as non-mobility of the sample and by visual inspection.

Figure 6. Variable temperature $500 \mathrm{MHz}{ }^{1} \mathrm{H}-\mathrm{NMR}$ spectra of $1.0 \%$ 5-chloro-8-hydroxyquinoline in $\mathrm{CD}_{3} \mathrm{OD} / \mathrm{D}_{2} \mathrm{O}(2: 1)$ from $+18{ }^{\circ} \mathrm{C}$ (bottom) to $+30{ }^{\circ} \mathrm{C}$ (top) in $2{ }^{\circ} \mathrm{C}$ steps. The clear increase in the signal intensity between $+28{ }^{\circ} \mathrm{C}$ and $+30{ }^{\circ} \mathrm{C}$ is due to the gel-to-sol transformation.

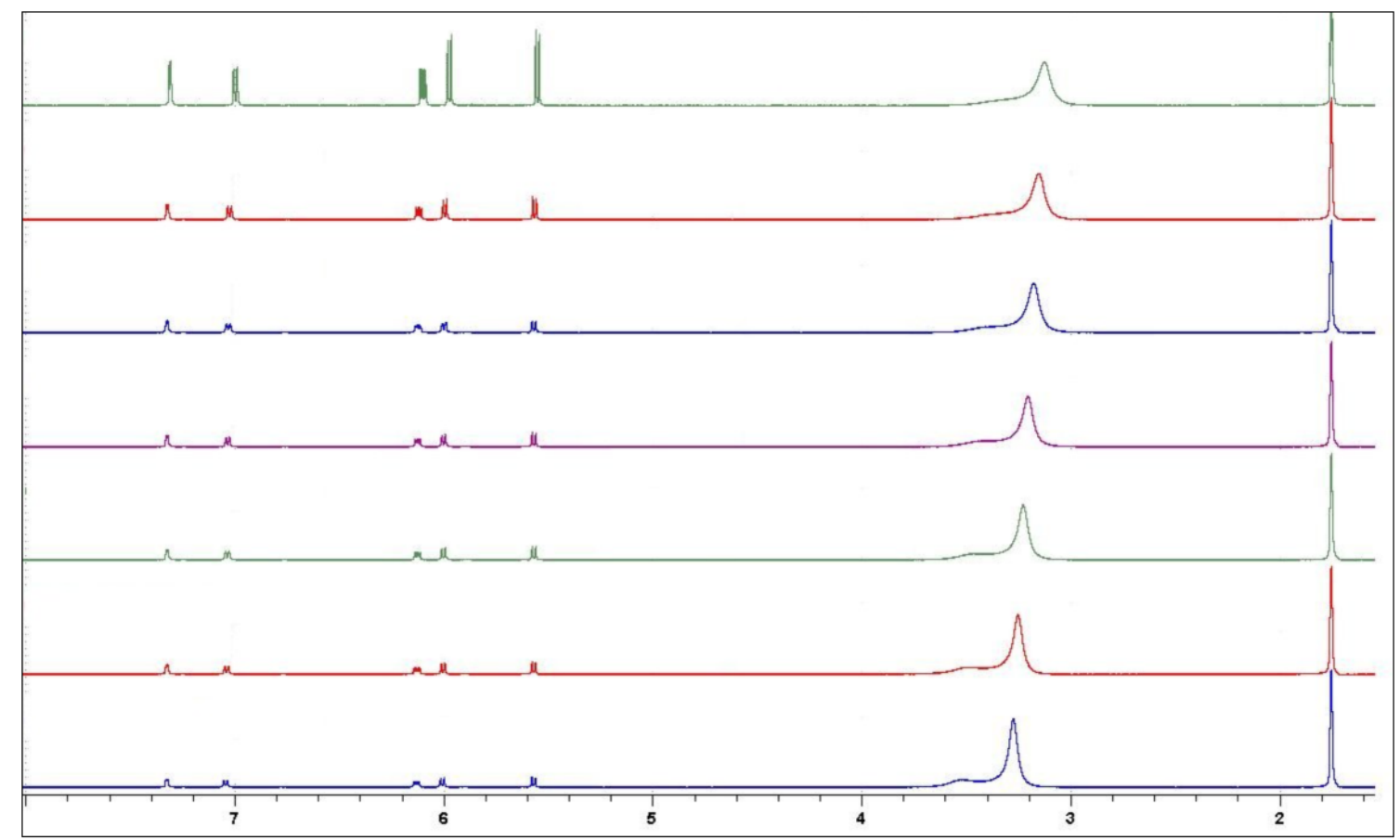

SEM images have been taken with Zeiss EVO 50 scanning electron microscope. In Figures 2-5 are also given the working distance $12.0 \mathrm{~mm}$ and acceleration voltage $19.99 \mathrm{kV}$.

VT ${ }^{1}$ H-NMR spectra were run with Bruker Avance DRX 500 FT NMR spectrometer in $\mathrm{CD}_{3} \mathrm{OD} / \mathrm{D}_{2} \mathrm{O} 2: 1$-mixture using $30^{\circ}$ flip angle and 4 scans. The chemical shift scale is referenced to the trace signal of $\mathrm{CHD}_{2} \mathrm{OD}$ at $3.31 \mathrm{ppm}$ from internal TMS.

\section{Conclusions}

It was shown that 5-chloro-8-hydroxyquinoline, an antituberculosis agent, efficiently gels aqueous alcohol solutions. A variable temperature ${ }^{1} \mathrm{H}-\mathrm{NMR}$ study reveals that the gel-to-sol transition of $1.0 \%$ 5-chloro-8-hydroxy-12-quinoline in $\mathrm{CD}_{3} \mathrm{OD} / \mathrm{D}_{2} \mathrm{O}(2: 1)$ happens between $+28{ }^{\circ} \mathrm{C}$ and $+30{ }^{\circ} \mathrm{C}$. Although this gel-to-sol transition takes place below the physiological conditions, this finding suggests that the gel stability could be improved by other modifications of solvent systems. This finding can be useful for the drug delivery and preparation of pharmaceutical formulations of 5-chloro-8-hydroxyquinoline.

\section{Acknowledgments}

We are grateful to Esa Haapaniemi for his help in VT NMR runs. 


\section{Conflict of Interest}

The authors declare no conflict of interest.

\section{References}

1. Dye, C. Global epidemiology of tuberculosis. Lancet 2006, 367, 938-940.

2. Ahmad, Z.; Makaya, N.H.; Grosset, J. History of drug discovery: Early evaluation studies and lessons learnt from them. Prog. Respir. Res. 2011, 40, $2-9$.

3. Hongmanee, P.; Rukseree, K.; Buabut, B.; Somsri, B.; Prasit, P. In vitro activities of cloxyquin (5-chloroquinolin-8-ol) against Mycobacterium tuberculosis. Antimicrob. Agents Chemother. 2007, 51, 1105-1106.

4. Darby, C.M.; Nathan, C.F. Killing of non-replicating Mycobacterium tuberculosis by 8-hydroxyquinoline. J. Antimicrob. Chemother. 2010, 65, 1424-1427.

5. Enquist, P.-A.; Gylfe, Å.; Hägglund, U.; Lindström, P.; Norberg-Scherman, H.; Sundin, C.; Elofsson, M. Derivatives of 8-hydroxyquinoline-Antibacterial agents that target intra- and extracellular Gram-negative pathogens. Bioorg. Med. Chem. Lett. 2012, 22, 3550-3553.

6. Ma, Z.; Moulton, B. A novel polymorph of 5-chloro-8-hydroxyquinoline with improved water solubility and faster dissolution rate. J. Chem. Crystallogr. 2009, 39, 913-918.

7. Fernández-Bachiller, M.I.; Pérez, C.; González-Munoz, G.C.; Conde, S.; López, M.G.; Villarroya, M.; García, A.G.; Rodríguez-Franco, M.I. Novel tacrine-8-hydroxyquinoline hybrids as multifunctional agents for the treatment of Alzheimer's disease, with neuroprotective, cholinergic, antioxidant, and copper-complexing properties. J. Med. Chem. 2010, 53, 4927-4937.

8. Kharadia, G.J.; Patel, J.R.; Dholakiy, B.Z. Antituberculosis, antifungal and thermal activity of mixed ligand transition metal complexes. Appl. Organomet. Chem. 2010, 24, 821-827.

9. Ma, Z.; Moulton, B. Mixed-Ligand Coordination Species: A Promising Approach for "SecondGeneration" Drug Development. Cryst. Growth Des. 2007, 7, 196-198.

10. Ma, Z.; Moulton, B. Supramolecular medicinal chemistry: Mixed-ligand coordination complexes. Mol. Pharm. 2007, 4, 373-385.

11. Pasipanodya, J.G.; Gumbo, T. A new evolutionary and pharmacokinetic-pharmacodynamic scenario for rapid emergence of resistance to single and multiple anti-tuberculosis drugs. Curr. Opin. Pharmacol. 2011, 11, 457-463.

12. Sangeetha, N.M.; Maitra, U. Supramolecular gels: Functions and uses. Chem. Soc. Rev. 2005, 34, 821-836.

13. Svobodová, H.; Noponen, V.; Kolehmainen, E.; Sievänen, E. Recent advances in steroidal supramolecular gels. RSC Adv. 2012, 2, 7840-7847.

14. Latosińska, J.N.; Latosińska, M.; Tomczak, M.A.; Seliger, J.; Žagar, V. Supramolecular synthon pattern in solid clioquinol and cloxiquine (APIs of antibacterial, antifungal, antiaging and antituberculosis drugs) studied by ${ }^{35} \mathrm{Cl}$ NQR, ${ }^{1} \mathrm{H}^{17}{ }^{17}$ and ${ }^{1} \mathrm{H}^{14} \mathrm{~N}$ NQDR and DFT/QTAIM. J. Mol. Model. 2011, 17, 1781-1800.

15. Svobodová, H.; Nonappa; Lahtinen, M.; Wimmer, Z.; Kolehmainen, E. A steroid-based gelator of $\mathrm{A}(\mathrm{LS})_{2}$ type: Tuning gel properties by metal coordination. Soft Matter 2012, 8, 3840-3847. 
16. Iqbal, S.; Rodríguez-LLansola, F.; Escuder, B.; Miravet, J.F.; Verbruggen, I.; Willemis, R. HRMAS ${ }^{1}$ H-NMR as a tool for the study of supramolecular gels. Soft Matter 2010, 6, 1875-1878.

17. Spectral Database for Organic Compounds. Available online: http://riodb01.ibase.aist.go.jp/sdbs/cgibin/cre_index.cgi?lang=eng (accessed on 18 September 2012).

(C) 2012 by the authors; licensee MDPI, Basel, Switzerland. This article is an open access article distributed under the terms and conditions of the Creative Commons Attribution license (http://creativecommons.org/licenses/by/3.0/). 